Gönderim Tarihi: 24.05.2018 Kabul Tarihi: 07.09.2018

\title{
KURUMLAR VERGİSİ ORANI-HASILAT İLIŞKİSİ: OECD ÖRNEĞİ
}

\author{
Gökhan DÖKMEN*
}

\section{CORPORATE TAX RATE-REVENUE RELATION: THE CASE OF OECD}

\begin{abstract}
$\ddot{O} z$
Küreselleşme sürecinde hükümetler, özellikle 1980'lerden sonra, yabanc1 sermayeyi çekmek için kurumlar vergisi oranlarını düşürmüştür. Ancak kurumlar vergisi oranlarında yaşanan azalmaya rağmen kurumlar vergisi gelirleri nispeten istikrarlı hatta artma eğilimi sergilemiştir. Literatürde "kurumlar vergisi oranıgelir paradoksu" olarak adlandırılan bu durum, şirketlerin kurumsallaşma düzeylerinde artma ve gelir vergisinden kurumlar vergisine doğru bir kaymayla açıklanmıştır. Kurumlar vergisi oranı ile hasılat arasındaki ters yönlü ilişki, vergi sistemlerinin tasarımı etkilemektedir. Nitekim günümüzdeki birçok ülke gelir vergisi ile kurumlar vergisi arasında bir tercih yapma ve vergi sistemlerini bu tercihe göre yeniden düzenleme eğilimdedir. $\mathrm{Bu}$ nedenle kurumlar vergisi paradoksunun geçerliliği ülkelerin vergi politikalarını etkileyen önemli bir konudur. $\mathrm{Bu}$ önemden dolayı bu çalışmada kurumlar vergi paradoksunun geçerliliği incelenmektedir. Çalışmada, bu paradoksal ilişkiyi incelemek için doğrusal olmayan regresyon tekniği kullanılmıştır. Analiz sonuçlarına göre, Laffer eğrisinin kurumlar vergisi açısından geçerli olduğu tespit edilmiş ve kurumlar vergisi gelirlerini maksimize eden oranın \%34 seviyesinde olduğu belirlenmiştir. $\mathrm{Bu}$ sonuç, kurumlar vergisi alanında son dönemde yaşanan değişimlerin ampirik açıdan teyit edilmesi açısından ve vergi politikasının tasarımı şekillendirme açısından oldukça önemlidir.
\end{abstract}

Anahtar Kelimeler: Kurumlar Vergisi Gelirleri, Kurumlar Vergisi Oran-Gelir Paradoksu, Laffer Eğrisi, Panel Veri.

\begin{abstract}
In the process of globalization, governments have lowered the rates of corporate taxes to attract foreign capital, especially after the 1980s. However, despite the declining rates of corporate tax, corporate tax revenues have displayed a relatively stable, even increasing tendency. This situation, which is referred to in the literature as "the rate of corporation tax rate-income paradox", is explained by the increase in the level of corporatization of companies and a shift towards the taxation of corporations from income tax. The inverse relationship between corporate tax rate and revenue affects the design of tax systems. Today, many
\end{abstract}

\footnotetext{
* Doç. Dr., Zonguldak Bülent Ecevit Üniversitesi, İIBF, Maliye Bölümü, e-posta: gokhan.dokmen@beun.edu.tr.
} 
countries are inclined to make a preference between income tax and corporation tax and organize their tax systems accordingly. For this reason, the validity of the corporate tax paradox is an important issue that affects the tax policies of countries. Because of this importance, the validity of tax paradox is examined in the study. In this study, nonlinear regression technique was used for examining this paradoxical relationship. According to the results of the analysis, it was determined that the Laffer curve was valid in terms of the corporate tax, and it was determined that the ratio of maximizing the tax incomes of the corporations was $34 \%$. This result is very important in terms of empirical confirmation of recent changes in corporate taxation and shaping the design of tax policy.

Keywords: Corporate Tax Revenue, Corporate Tax Rate-Revenue Paradox, Laffer Curve, Panel Data.

\section{Giriş}

Kurumlar vergisi oranları 1980'lerin ortalarından itibaren istikrarlı bir biçimde azalma eğilimdedir. Bu eğilim, küreselleşme teorileri, sermaye hareketliliği ve vergi rekabeti ilişkisi bağlamında ele alınmakta ve açıklanmaya çalışılmaktadır. Vergi oranlarındaki azalma eğilimi küresel ölçekte geçerli olmakla birlikte özellikle gelişmiş ülkelerde ortaya çıkan dinamikler çok daha dikkat çekicidir. Çünkü bu ülkelerde yapılan kurumlar vergisi reform çalışmaları ile vergi oranlarını azaltmaya yönelik bir trend ortaya çıkmıştır. Söz konusu trend, dış ticaret hacminin arttığ1, doğrudan yabancı yatırımların hızlandığ1 ve küreselleşme eğilimlerinin şiddetini arttırdığı bir dönemde gerçekleştiği için sermaye hareketliliğine bağlı olarak ülkeler arasında vergi rekabetinin düzeyi de artmıştır. Buna ek olarak; firmalar, düşük vergi oranlarının olduğu ülkelerde daha karlı yatırım stratejilerini hayata geçirmek amacıyla doğrudan yabancı sermaye yatırımları ve transfer fiyatlaması gibi yöntemlere odaklanmıştır. $\mathrm{Bu}$ nedenle günümüzde düşük vergi oranlarına sahip olmanın faydaları, yüksek vergi oranlarına sahip olmanın maliyetlerinden büyüktür (Brill ve Hassett 2007:4).

Küreselleşmenin geldiği son aşamada, artan sermaye hareketliliğine bağl1 olarak yüksek vergi oranları sonucunda kurumlar vergisinin hasılatında bir azalma ortaya çıkabilir. Teorik olarak, çok uluslu firmaların yer seçim kararlarının esnek olmasından dolayı, vergi oranlarının seviyesi oldukça önem kazanmaktadır. Böyle bir hareketliliğin olmadığı bir dünyada, yüksek vergi oranları ile hasılatın arttırılması oldukça mümkündür. Ancak bugünün ekonomik iklimi ve ülkeler arasındaki ekonomik ilişkiler, sınırların öneminin giderek azaldığı bir dünyayı gözler önüne sermekte ve buna bağlı olarak da kurumlar vergisi oranı ile hasılat arasındaki ilişki doğrusal bir biçimden uzaklaşabilmektedir. 
$\mathrm{Bu}$ çalışma, uluslararası ekonomik ilişkilerin giderek birbirine bağlı hale geldiği bir konjonktürde, kurumlar vergisi oranları ile gelir arasındaki ilişkiyi test etmek amacıyla yapılmıştır. Çalışmada söz konusu ilişki, OECD ülkelerine yönelik bir örneklemle incelenmiştir. Kurumlar vergisinin oranları ile kurumlar vergisi hasılatı arasındaki ilişkinin Laffer eğrisi formunda modellenebilmesi için lineer olmayan regresyon tekniği kullanılmıştır. Bu bağlamda çalışmada, kurumlar vergisinin hasılatını maksimize etme oranının varlığı ve zaman içindeki eğilimi analiz edilmiştir.

\section{Kurumlar Vergisinin Sistematik Gelişimi}

19. Yüzyılın sonlarından itibaren sanayileşmiş ülkelerde tüzel kişiliğe haiz anonim, limited, komandit gibi farklı yapılardaki şirketlerin hızla artması, gerçek kişilerin gelirlerini tamamlayıcı nitelikte olan kurumlar vergisine olan ihtiyacı arttırmıştır. Böylece gerçek kişiler gibi ekonomik faaliyetleri sonucunda kar ele eden "kurumlar"'n elde ettikleri kurum kazancı üzerinden alınan bir vergi türü olarak kurumlar vergisi ortaya çıkmıştır. Ancak kurumlar vergisinin gelişimi her ülkede aynı şekilde olmamış; sanayileşme sürecindeki gelişmelere bağlı olarak Batı Avrupa ülkelerinden diğer ülkelere doğru bir yayılım sergilemiştir (Şen ve Sağbaş 2015:195).

Almanya'da kurumların vergilendirilme süreci, 19. Yüzyılın ortalarında gündeme gelmiştir. Bu dönemde anonim şirketlerde görülen hızlı büyüme süreci, sermaye şirketlerinin yürürlükteki gelir sistemine dahil edilmesine ilişkin çeşitli tartışmaları ortaya çıkarmıştır. Bu tartışmalar sonucunda kurumların elde ettikleri gelirler, 1891 tarihli Prusya Gelir Vergisi Reformu'nda gerçek kişilerle aynı vergi yükümlülügüne tabi olmuş; 1920 yılında ise vergi tarifesi itibariyle gelir vergisinden farklı olan ve bütün tüzel kişileri yükümlü kılan gerçek anlamda bir kurumlar vergisi kabul edilmiştir. İngiltere'de 1937 yılına kadar gelir vergisinden ayrı bir kurumlar vergisi uygulanmamıştır. 1937 yılında Ulusal Savunma Katkısı (National Defence Contribution) adı altında bir vergi uygulamasına gidilmiş ancak bu vergi sermaye şirketlerinin yanı sıra gerçek kişilerin ticari gelirlerini de yükümlü kıldığı için gerçek anlamda bir kurumlar vergisi niteliğine sahip olmamıştır. Günümüzdeki biçimiyle gerçek bir kurumlar vergisi uygulaması ise 1947 yılında hayata geçirilmiştir. Kişisel gelir vergisinden bağımsız bir kurumlar vergisinin doğuşu, Fransa' da da oldukça yakın bir tarihe dayanmaktadır. 1917 tarihli Fransız gelir vergisi, sermaye şirketlerinin gerek dağıtılan, gerekse dağıtılmayan kazançlarını yükümlü kılmakta birlikte gerçek anlamda bir kurumlar vergisinin kabulü, 1948 yılında olmuştur. Amerika Birleşik Devletleri'nde genel 
servet vergisinin başarısızlığa uğraması üzerine, ilk olarak geçen asrın ortalarına doğru federe devletlerde özel bir vergi olarak ortaya çıkmış olan kurumlar vergisi, Birinci Dünya Savaşı'ndan sonra özel bir tarifeye sahip bağımsız bir vergi haline gelmiştir. Türkiye'de ise kurumların gelir vergisi dışında ayrı bir vergiye tabi tutulması, 1950 yılında yürürlüğe konulan Kurumlar Vergisi Kanunu ile düzenlenmiştir (Turan 1998:133135).

Kurumlar vergisi, iktisadi faaliyetleri sonucu kar elde eden kurumların net kazançları üzerinden gelirin doğduğu aşamada alınan genel nitelikte bir dolaysız vergidir. Kurumlar vergisinin temel özellikleri aşağıdaki gibi sıralanabilir (Şen ve Sağbaş 2015:196):

- Mükellefleri tüzel kişiliğe haiz ve haiz olmayan kurum ve kuruluşlar, konusu ise bu kurum ve kuruluşların bir takvim yılı içinde elde etmiş oldukları kazanç ve iratların safi tutarıdır.

- Dolaysız ve objektif bir vergidir.

- Küreselleşme ile birlikte tarife yapıları değişen bir vergi türüdür. $\mathrm{ABD}$, Almanya ve Macaristan gibi bazı ülkelerdeki istisnai uygulamalar hariç tutulduğunda genelde düz oranlı olarak uygulanan bir vergidir.

- Kurumsallaşmayı arttıran, uluslararası rekabet gücünü etkileyen, gelir yaratma potansiyeli oldukça yüksek bir vergidir.

Vergi sistemi içerisinde önemli bir yeri olan kurumlar vergisinin ekonomik etkileri, mikro ve makro perspektiften ele alınmaktadır. Kurumlar vergisi mikro ölçekte firma davranışları açısından değerlendirilmektedir. Verginin; kar dağıtımı, tasarruf, yatıım, firma ölçeği (büyüklüğü) ve finansman gibi firma davranışlarına olan etkisi, mikro perspektifin birer yansımalarıdır. Makro perspektif ise verginin toplam tasarruf, yatırım ve tüketim ile kaynak ve gelir dağılımı üzerindeki etkiler bağlamında ulusal ve uluslararası boyutta yapılmaktadır. Ulusal boyut açısından bakıldığında kurumlar vergisinin ülke içinde seçici bir biçimde uygulanması, şirketlerin yatırım ve tasarruf kararlarında olduğu kadar kaynak dağılımındaki etkinliği de etkilemektedir. Kurumlar vergisinin uluslararası boyutu, sermayenin uluslararası hareketliliği dikkate alındığında, ulusal boyuttan daha fazla öne çıkmaktadır. Nitekim küreselleşme eğilimlerinin hızlanması sonrasında etkisi giderek artan doğrudan yabancı yatırımlar ve uluslararası vergi rekabeti, mobilitesi yüksek sermaye üzerinde bir maliyet unsuru oluşturan kurumlar vergisinin önemini daha da arttırmıştır (Öncel 2005:3). 
Uluslararası ticari ilişkilerin boyutunun giderek arttı̆̆ bir süreçte, kurumlar vergisi alanında ortaya çıkan gelişmeler hem ekonomistlerin hem de politikacıların dikkatini çekmektedir. Küreselleşme ve çok uluslu işletmelerin etkileşimi noktasında, bir ülkenin ulusal egemenlik hakkının en temel yansıma biçiminin görüldüğü vergileme alanında bir takım olumsuzluklar yaşanması beklenebilir. Örneğin, ülkelerarasındaki vergi rekabeti "dibe doğru yarış" olarak adlandırılan ve kurumlar vergisi oranlarının azaltılmasına yönelik bir eğilimi ortaya çıkarmıştır. Diğer taraftan vergi gelirleri, uluslararası vergi sistemlerinin karmaşı etkileşimlerinden yararlanan şirketlerin gelişmiş vergi planlamasından dolayı azalma tehdidi altına girmiştir (Abbas ve Klemm 2012:3).

Kurumlar vergisinin oran ve gelir yapısındaki değişimler küresel ölçekte ortaya çıkmaktadır. Dünya çapında ortalama yasal kurumlar vergisi oranı, 1980 yllında \% 38.68 seviyesinde iken; 2017 yılında \% 22.96 seviyesine gerilemiştir. Dünyadaki pek çok bölge, 1980 ve 2017 yılları arasında ortalama yasal oranlarda net bir düşüş kaydetmiştir. En büyük düşüş trendi, Avrupa kıtasında gerçekleşmiş ve 1980'lerdeki \% 40.5 seviyesinden; 2017 yılında \% 18.35 seviyesine gerilemiştir. Benzer şekilde, Afrika, Okyanusya ve Güney Amerika'da ortalama yasal oranın arttığ1 yıllar görülmekle birlikte; tüm bölgelerdeki ortalama oranlar, 1980-2017 dönemi boyunca azalma trendinde olmuştur. Kurumlar vergisinin oran yapısındaki azalma eğilimi dışındaki genel eğilimler aşağıda gösterilmiştir (Jahnsen ve Pomerleau 2017):

- Büyük sanayileşmiş ülkeler gelişmekte olan ülkelere göre daha yüksek kurumlar vergisi oranlarına sahip olma eğilimindedir.

- Dünya ortalama yasal kurumlar vergisi oran1 \%22.96'dır. GSYH'ye göre ağırlıklandırıldığında ise ortalama yasal oran \%29.41'dir.

- Dünyanın en yüksek kurumlar vergisi oranına sahip olan ülkeleri sırasıyla Birleşik Arap Emirlikleri, Komorlar ve Porto Riko'dur. Amerika Birleşik Devletleri dünyanın dördüncü en yüksek kurumlar vergisi oranına sahip olup, kurum kazançlarına \%38.91 oranında vergi uygulamaktadır.

- Kurumlar vergisinde Avrupa, \%18.35 ile (GSYİH'ye göre ağırlıklandırıldığında \%25.58) en düşük bölgesel ortalama orana sahiptir. Afrika ve Güney Amerika ise en yüksek bölgesel ortalama oranına sahip olup; kurumlar vergisi ortalamas1 \% 28.73'dür (Afrika için GSYIH'ya göre \%28.2; Güney Amerika için GSYH'ya göre \%32.98).

Kurumlar vergisi hemen hemen bütün ülkelerde farklı biçimlerde uygulansa bile küresel ölçekte gerek oran gerekse de hasılat açısından ortak bir trende sahiptir. Şöyle ki; kurumlar vergisi hasılatı dönemsel bir 
biçimde istikrarını korumakta hatta kısmi olarak artma eğilimdedir. Kurumlar vergisinin gelirlerinin GSYİH'ya oranının OECD ülkelerindeki ortalamas1 1965 yılında \% 2.13 iken; bu oran 2015 y1lında \% 2.80 olmuştur. Benzer bir eğilim, kurumlar vergisi gelirlerinin toplam vergi gelirleri içindeki payı açısında da geçerlidir. 1965 yılında toplam vergi gelirlerinin \% 8.8'i kurumlar vergisinden elde edilmişken; bu oran 2015 yılında \% 8.9 ile 1965 'ler seviyesini korumuştur. OECD ortalaması göstermektedir ki kurumlar vergisi gelirleri istikrarlı bir eğilim sergilemiş hatta artma eğilimi göstermiştir. Benzer bir durum, Avrupa Birliği ülkeleri açısından da geçerlidir. İngiltere'de kurumlar vergisinin GSYİH'ya oranı 1965 yılında 1.33 iken; 2015 y1lında ise 2.81 seviyesine ulaşmıştır. Avrupa Birliği'nde 1965 yılında en yüksek GSYİH'nın yüzdesi olarak kurumlar vergisi oranı Lüksemburg'da görüşmüş ve oran \% 2.91 olarak gerçekleşmiştir. Bu oran 2015 y1lında \% 4.54 seviyesine ulaşmıştır (OECD 2018).

\section{Kurumlar Vergisi Oranı-Hasılat İlişkisi: Teorik Temeller}

Mevcut ulusal vergi sistemleri, ağırlıklı olarak ticaretin korunması ve sermaye ile işgücü hareketsizliğinin yaygın olduğu 2. Dünya Savaşı'ndan sonra tasarlanmıştır. Bu vergi tasarımı, farklı ve dolaysız vergilendirme oranlarının uygulanmasını mümkün kılmıştır. Ancak küreselleşme eğilimlerinin ekonomik yaşamın hemen hemen her alanında etkisini arttırması ile birlikte ulusların birbirlerine bağlılığı (teknolojik ve sosyal alanlarda ve ayrıca kültürel olarak) giderek artmış ve vergi sistemlerinin tasarımı değişmeye başlamıştır.

Ülkeler arasındaki üretim faktörlerinin hareketliliğinde ve aynı zamanda birden fazla ülkede faaliyet gösteren şirketlerin sayısında artışa yansıyan küreselleşme süreci, kurumlar vergisi tabanında da önemli değişimlere neden olmuştur. Çok uluslu şirketlerin faaliyetlerinin artması, üretim sürecinin uluslararasılaşması, üretim sürecine dahil olan ülkelerin sayısındaki artış, yabancı işlemlerde daha fazla karmaşıklık ve iletişim teknolojilerindeki bir devrim nedeniyle uluslararası ticarette coğrafi sınırların öneminde önemli bir azalma ortaya çıkmış (Spence, 1997) ve kurumlar vergisinin diğer ülkelerden bağımsız olarak uygulanma imkanı sinırlanmıştır.

Ticari faaliyetlerin uluslararasılaşması, dünya çapında ulusal kurumlar vergisi sistemleri üzerinde önemli baskılar yaratmıştır. Kurumlar vergisi oranlarının ülkelerarasında farklılaşması, rekabet eden ülkelerin gelirlerinin çifte vergilendirilmesi ve vergi cennetleri gibi uygulamalar eşgüdümlü olmayan ulusal kurumlar vergisi politikalarını ortaya çıkarmıştır. İşletmeler operasyonlarını küreselleştirdikçe, uluslararası 
düzeyde karmaşık vergi kuralları ve düzenlemeleri ile verimsiz bir kurumlar vergisi ile karşı karşıya kalınmıştır (Mintz, 1999:389).

Küreselleşme ve uluslararası sermaye rekabetinin vergi sistemlerine yansıması en net biçimde kurumlar vergisi oranlarında azalma şeklinde olmuştur. Ancak bu azalmaya rağmen kurumlar vergisi hasılatında aşırı bir düşüş olmamış hatta belli dönemlerde artışlar yaşanmıştır. Kurumlar vergisi oranlarının düşmesi ile kurumlar vergisi gelirlerinin artması arasındaki tutarsızlık, genellikle kurumlar vergisi tabanının genişletilmesinin bir sonucu olarak görülmektedir (Albi 2010:15). Nitekim kurumlar vergisi oranlarındaki azalmaya, birçok OECD ülkesindeki yatırım indirimi, geçmiş yıllara ilişkin zararların mahsubu ve amortisman uygulamaları gibi vergi tabanını genişletmeye yönelik politikalar eşlik etmiştir. Ĕger kurumlar vergisi oranları ile vergi gelirleri arasındaki ilişki, sadece vergi tabanını genişlemeye yönelik politikalara dayalı olarak açıklanabilseydi, literatürde dibe doğru yarış olarak kavramsallaştırılan ve ülkelerin yabancı sermayeyi kendi ülkelerine çekebilmek için vergi oranlarını indirmelerine dayalı politikaların olumsuz etkilerini tartışmak çok anlamlı olmayacaktı. Oysaki firmaların ortalama efektif vergi oranlarına ilişkin olarak yapılan çalışmalarda, bu oranlarında düşüş eğilimde olduğunu vurgulanmıştır. $\mathrm{Bu}$ nedenle vergi tabanını genişletme politikalarının sadece kurumlar vergisi oranlarındaki indirimin hasılatta neden olduğu azalmayı bertaraf etmek için yapılmadığı sonucuna ulaşılabilir. $\mathrm{Bu}$ sonuç kurumlar vergisi oranlarındaki azalma ile hasılat artışı arasındaki ilişkiye yönelik olarak farklı açıklamalara gereksinim olduğunu göstermektedir (Mooij ve Nicodème 2008).

Literatürde dikkate alınan önemli açıklamalardan biri, kurumlar vergisi sisteminin özellikleri ile ilgilidir. Auerbach (2006), kurumlar vergisi oranlarındaki azalma sonucunda vergi hasılatının azalmaması için firmalar üzerindeki örtük vergi yüklerinde önemli artışların olduğunu; bu nedenle kurumlar vergisi hasılatının Amerika Birleşik Devletlerinde (ABD) istikrarlı olduğunu ifade etmektedir. Nitekim ABD'de GSYİH'nın bir payı olarak finans sektörü dışındaki şirketlerin vergi gelirleri, 1960'ların sonlarında ve 1970'lerde hızla düştükten sonra, 1980'lerin başlarından itibaren nispeten sabit kalmıştır. Ancak bu göreceli istikrar, finans sektörü dışındaki şirket karlarının GSYH'ya oranındaki azalmanın bu karlar üzerindeki vergi yükündeki artışla dengelenerek sağlanmıştır (Auerbach 2006:14). Benzer bir açıklama, Creedy ve Gemmell (2009) tarafından da yapılmıştır. Çalışmada, Birleşik Krallık'taki kurumlar vergisi sisteminin, kar ile ilgili gelir esnekliği ile ölçülen yerleşik esneklik (built in flexibility) özellikleri incelenmiş ve kurumlar vergisi gelirlerinin 
artmasının şirket karlılığının artmasına dayalı olarak yüksek volatiliteye sahip olduğu ifade edilmiştir. Çalışmada, gelir esnekliğindeki yüksek volatilitenin, özellikle ekonomik daralmalar ile ilişkili olduğu bulgusuna ulaşılmıştır. Hafif ekonomik durgunluk dönemlerinde, vergi gelirlerindeki artış karlardaki artıştan daha az olduğundan, kurumlar vergisi gelir esnekliğinin artabileceği; ancak daha ağır ekonomik daralma dönemlerinde gelir esnekliğinde büyük fakat geçici azalmalar (ve hatta olumsuz esneklikler) beklenebileceği ifade edilmiştir. Bu yönüyle Creedy ve Gemmell (2009), Birleşik Krallık'taki kurumlar vergisi gelirlerinin 1992-2004 yıllarındaki istikrarlı eğiliminin vergi sisteminin mali sürüklenme özelliklerinden kaynaklandığını vurgulamıştır.

Ekonominin sektörel yapısındaki değişim ve bazı sektörlerin reel ekonomideki ağırlığının artması, kurumlar vergisi oranları ile hasılat arasındaki ilişkinin anlaşılmasında kullanılan bir diğer açıklama biçimidir (Piotrowska ve Vanborren 2008). Devereux vd. (2002), kurumlar vergisi oran ve hasılatı arasındaki ilişkiyi, Birleşik Krallık açısından incelemiştir. Çalışmada, vergi sistemini etkileyen faktörlerinin gelirler üzerindeki etkileri, efektif marjinal vergi oranı ve kurumlar vergisi gelirlerinin şirket karlarına bölünmesiyle elde edilebilecek ortalama efektif vergi oranı kavramları kullanılarak analiz edilmiştir. Yapılan çalışmada, oran-hasılat arasındaki ilişkinin açıklanmasında sadece vergi tabanının genişletilmesi değil aynı zamanda hizmet sektöründeki yüksek karlılığın kurumlar vergisi gelirlerindeki artışa katkıda bulunmasının da etkili olduğu ifade edilmiştir.

Clausing (2007), kurumlar vergisinin GSYİH'ya oranını etkileyen faktörlere ilişkin sistematik bir çalışma yapmıştır. OECD ülkeleri dikkate alınarak yapılan çalışmada; yasal vergi oranı, vergi tabanı, kurumsal karlılık, GSYH içindeki kurumsal sektörlerin payı, bireysel ve kurumlar vergisi tabanları arasındaki kayma ve uluslararası faktörler kurumlar vergisi hasılatı üzerindeki etkiler bağlamında incelenmiştir. Analiz sonuçlarına göre, ekonomide kurumsal sektörlerin ağırlıkta olduğu ve daha yüksek kurumsal karlılık oranına sahip olan ülkelerde, vergi-GSYİH oranı diğger ülkelere kıyasla daha yüksektir.

Sørensen (2007), oran-gelir paradoksunun şirketleşmenin arttırılmasıyla açıklanabileceğini öne sürmektedir. Sørensen'a (2007:175-179) göre, açık olan küçük bir ekonominin yöneticileri, sermaye üzerindeki düşük vergiler yoluyla iç reel yatırımı teşvik etmek istiyorsa, kurumlar vergisi gibi yatırım odaklı kaynaklara dayalı vergileri düşürmeye odaklanmalıdır. Vergi oranlarındaki azalmaya rağmen kurumlar vergisi hasılatının GSYİH'ya oranının artmasının olası nedeni, kurumsal şirketlerin kurumsal olmayan şirketlere oranla nispi olarak daha yüksek paya sahip 
olmasıdır. Bu durum kısmen kurumsal olmayan örgütsel formun hakim olduğu tarım gibi belirli sektörlerin ağırlığındaki azalma; kısmen de kurumlar vergisi oranlarındaki büyük düşüşlerin neden olduğu kurumsal sektöre yönelik gelir kaydırılması (income shifting) ile açıklanabilir. Her iki durumda da, kurumlar vergisi gelirindeki artış, kişisel gelir vergisinden elde edilen gelir kaybıyla dengelenecektir.

Benzer bir açıklama, De Mooij ve Nicodème (2007) tarafından yapılmış ve Avrupa'daki kurumlar vergisi oranlarındaki azalma ile artan vergiGSYİH oranının büyük oranda şirketleşmenin artması ve kişisel gelirlerin kurumlar vergisine kaydırılması ile açıklanmıştır. De Mooij ve Nicodème (2007), girişimcilerin iş yapmanın yasal biçimine karar verme sürecinde vergi sistemlerinden etkilendiğini ifade ederek; işletmelerin kişisel gelir vergisi rejimi ile kıyaslandığında kurumlar vergisi rejimi altında daha hafif vergilendirilmeleri durumunda, yasal biçimlerini kurumsal işletmelere doğru kaydırmakta olduklarının altını çizmektedir. Weichenrieder (2005) tarafından yapılan çalışmada, Avusturya'da, kurumsal şirketlerin ekonomideki payının 1970'lerin ortalarında \%50'ler seviyesinde iken; bu oranın günümüzde \% 75'ler seviyesine ulaştığı ifade edilmiştir. Benzer bir eğilim, Almanya açısından da geçerli olmuş; kurumsallaşma seviyesinin söz konusu y1llarda \%40; günümüzde ise \%55'ler seviyesinde olduğunun altı çizilmiştir. $\mathrm{Bu}$ sonuçlar; kurumsallaşmanın artan önemine ve bu noktada vergi rejimindeki farklılı̆̆ın etkisine işaret etmektedir.

Kurumlar vergisi oranı-gelir paradoksunun açıklanmasına yönelik bir diğer açıklama ise kurumsal karlılık seviyesidir. Swiston vd. (2007) tarafından ABD ekonomisine ilişkin olarak yapılan bir çalışmada, şirket karları ve sermaye kazançlarındaki büyümenin 2004-2006 yılları arasındaki kurumlar vergisi gelirinin GSYİH'ya oranındaki artışın yüzde kırkına katkıda bulunduğu ifade edilmiştir. Çalışmada, vergi oranlarındaki azalma sonucunda karlılığın arttığı ve buna bağlı olarak da vergi gelirlerinin yükseldiği vurgulanmıştır.

\section{Literatürde Yapılan Çalışmalar}

$\mathrm{Bu}$ çalışma, kurumlar vergisi oranlarındaki bir azalmanın vergi hasılatı üzerinde neden olduğu artışı teorik bir düzlemde ele almakta ve ampirik olarak kurumlar vergisinin hasılatını maksimize etme oranının varlığını araştırmaktadır. Bu nedenle kurumlar vergisinin oranları ile kurumlar vergisi hasılatı arasındaki ilişkinin Laffer eğrisi formunda modellendiği çalışmalar incelenmiştir. Clausing (2007), OECD ülkelerine ilişkin bir örneklem kullanarak, 1979-2002 yılları arasında, GSYİH'ye göre kurumlar vergisi gelirlerindeki değişimi ampirik olarak incelemiştir. 
Ampirik sonuçlar, vergi oranları ile gelirler arasında parabolik bir ilişki olduğunu göstermiştir. Şöyle ki; tüm OECD örneklemi için \% 33'lük bir kurumlar vergisi oranı gelir seviyesini maksimize etmektedir. Çalışmada, kurumlar vergisi gelirlerini maksimize eden bu oranın, ekonomilerin daha küçük ve dünya ekonomisine daha fazla entegre olmasıyla azaldığ1 bulgusuna da ulaşılmıştır.

Brill ve Hassett (2007), 1981-2002 dönemi için 29 OECD ülkesinden oluşmakta olan bir örneklem kullanarak, Laffer eğrisini test etmiştir. Test sonuçlarına göre, örneklem döneminin çoğunda kurumlar vergisi alanında bir Laffer eğrisinin var olduğuna dair sağlam kanıtlar bulunmuştur. Çalışmada, 1980'lerin sonlarında kurumlar vergisi gelirlerini maksimize eden oranın yaklaşık \%34 seviyesinde gerçekleştiği ve bu oranın son dönemlerde \%26'ya düştüğü tespit edilmiştir (Brill ve Hassett 2007).

Stinespring (2009), Laffer eğrisinin varlığını ve şeklini belirlemek amacıyla, 1996-2007 döneminde 50 ülke örneklemi kullanarak, kurumlar vergisi oranlarının kurumlar vergisi gelirleri üzerindeki etkisini incelemiştir. Analiz sonuçları, Laffer eğrisinin varlığına ilişkin kanıtlar sunmuş ve gelir-maksimize oranının zamanla azaldığını göstermiştir. Şöyle ki; geliri maksimize eden kurumlar vergisi oranları, 1996-2002 döneminde \% 8.52 ila \% 9.32; 2003-2007 döneminde ise \% 6.03 ila \% 7.47 arasında değişmektedir. Çalışmada ayrıca; 2002 yılında 8 ülkenin, 2007 yılında ise 22 ülkenin Laffer eğrisinin sağ tarafında yer aldığ bulgusuna ulaşılmıştır. Söz konusu bulgulara dayanılarak, bu ülkelerdeki vergi oranlarında indirime gidilerek daha yüksek vergi hasılatının sağlayabileceğine ilişkin değerlendirme yapılmıştır.

Vogel (2012) açık bir ekonomide Yeni-Keynesyen dinamik genel denge modeli kullanarak yaptığı çalışmada, kurumlar vergisi hasılatı maksimum kılan vergi oranını, mevcut $\mathrm{AB}$ ortalamasındaki örtülü vergi oranlarına kıyasla, \% 72 gibi oldukça yüksek bir seviyede olduğunu tespit etmiştir.

Monteiro vd. (2011), Avrupa Birliği'nin son 12 yıldaki kurumlar vergisi gelir performansını, 1998-2009 döneminde, 27 üye ülke açısından panel veri seti kullanılarak incelemiştir. Uygun Genelleştirilmiş En Küçük Kareler (Feasible Generalized Least Squares) yöntemi kullanılarak yapılan ampirik çalışmanın sonuçları, Laffer eğrisinin varlığına ilişkin kanıtlar sunmakta olup, efektif marjinal vergi oranı ile kurumlar vergisi gelirleri arasında parabolik bir ilişki tespit edilmiştir. Şöyle ki, kurumlar vergisi hasılatı maksimum kılan vergi oranı \% 25 seviyesinde çıkmıştır. Çalışmada, gelir seviyesini maksimum yapan kurumlar vergisi oranının mutlaka optimal kurumlar vergisi oranına tekabül etmeyeceği, ancak 
vergi oranları ile gelirler arasındaki ilişkinin önemli bir politika aracı olarak kullanılabileceği ifade edilmiştir.

Herbst (2008), 1965-2006 dönemine ilişkin olarak, 20 OECD ülkesi için, Laffer eğrisinin kurumlar vergisinde geçerli olup olmadığını analiz etmiştir. Çalışmada, hem ayrı ayrı ülke analizi (İrlanda, Fransa ve Birleşik Krallık) hem de OECD örnekleminin bütünü üzerinde tahmin yapılmıştır. Seçilen üç OECD ülkesinde, Laffer etkilerini tahmin edilmiş ve her ülke için en uygun model tahmin edilmeye çalışılmıştır. Model sonuçlarına göre, kurumlar vergisi hasılatını maksimize eden oranlar ülkelere göre değişmekte olup; oranlar İrlanda'da \% 26, Fransa'da \% 34 ve Birleşik Krallık'ta ise \% 44 seviyesinde gerçekleşmiştir. Her üç ülkede vergi oranlarının Laffer eğrisinin normal alanında olduğu sonucuna ulaşılmıştır. Panel veri tahmin sonuçları tüm örneklem dikkate alındığında ise kurumlar vergisi hasılatını maksimize eden oranın yaklaşık \% 41 seviyesinde olduğunu bulgusuna ulaşılmıştır.

Brender ve Politzer (2014), 1991-2012 döneminde meydana gelen tüm değişiklikleri içeren bir veri tabanını kullanarak, İsrail'deki vergi gelirlerinin, kanuni vergi oranındaki değişikliklerinden ne ölçüde etkilendiği üzerine bir çalışma yapmıştır. Laffer eğrisindeki ilişkinin İsrail ekonomisi açısından test edildiği çalışmada, vergi oranlarında yapılan indirimlerin vergi gelirlerinde düşüşe yol açtığ 1 ; vergi oranlarındaki artışların ise vergi gelirlerini artırdığ bulgusuna ulaşılmıştır. Bu sonuç, vergi oranlarındaki indirimlerin gelirleri arttırdığı görüşünün geçerli olmadığını, başka bir ifadeyle Laffer eğrisindeki ilişkinin İsrail ekonomisi açısından doğrulanmadığını göstermiştir.

\section{Kurumlar Vergisi Oranı-Hasılat İlişkisine Yönelik Ampirik Uygulama}

$\mathrm{Bu}$ çalışma, kurumlar vergisi gelirlerini maksimize eden oranı belirlemek, başka bir ifadeyle Laffer eğrisinin kurumlar vergisinde geçerli olup olmadığını test etmek amacıyla yapılmıştır. Çalışma, kurumlar vergisinin oran yapısının dönemsel olarak azalma eğilimde olduğu OECD ülkelerine yönelik panel veri analizini kapsamaktadır.

\subsection{Veri Seti ve Değişkenler}

Çalışmada, kurumlar vergisi oran-hasılat ilişkini test etmek amacıyla 2000-2015 yılları arasında 26 OECD ülkesinden oluşan örneklem 
kullanılmıştır' ${ }^{1}$ OECD'deki diğer ülkeler ise veri problemi nedeniyle çalışmaya dahil edilememiştir. Analizde kullanılan değişkenlerin tanımları ve kaynakları aşağıda gösterilmiştir.

Tablo 1: Analizde Kullanılan Değişkenler

\begin{tabular}{|lcc|}
\hline Değişken & Tanım & Kaynak \\
\hline Corgdp & $\begin{array}{c}\text { Kurumlar vergisi gelirlerinin } \\
\text { GSYIH'ya oranı }\end{array}$ & OECD Statistics \\
\hline Corrate & Kurumlar vergisi oranları & OECD Statistics \\
\hline Corratesq & Kurumlar vergisi oranlarının karesi & OECD Statistics \\
\hline Corshare & $\begin{array}{c}\text { Kurumların katma değer toplamının } \\
\text { GSYİH'ya oranı }\end{array}$ & OECD Statistics \\
\hline Profit & $\begin{array}{c}\text { Kurumların işletme artığının katma } \\
\text { değere oranı }\end{array}$ & OECD Statistics \\
\hline Gdp & GSYİH'daki yıllık büyüme oranı & $\begin{array}{c}\text { World Development } \\
\text { Indicators (WDI) }\end{array}$ \\
\hline Unemp & $\begin{array}{c}\text { Toplam işgücünün yüzdesi olarak } \\
\text { işsizlik oranı }\end{array}$ & $\begin{array}{c}\text { World Development } \\
\text { Indicators (WDI) }\end{array}$ \\
\hline Ratedif & $\begin{array}{c}\text { En yüksek yasal gelir vergisi oranı- } \\
\text { kurumlar vergisi oranı }\end{array}$ & OECD Statistics \\
\hline
\end{tabular}

Kurumlar vergisi oran-hasılat ilişkisini analiz ederken iki değişken oldukça önemlidir. Bunlardan birinci kurumların katma değer toplamı; diğeri ise gayrisafi işletme artığı ve karma gelir toplamıdır. Corshare olarak adlandırılan kurumların katma değer toplamının GSYİH'ya oranı, bir ülkedeki kurumsal yapının büyüklüğünü belirleme noktasında önemli bir değişkendir. Diğer değişken ise gayrisafi işletme artı̆̆ 1 ve katma değerdir. İşletme artığı, katma değerden net dolaylı vergiler, sabit sermaye tüketimi ve işgücü ödemelerinin düşülmesiyle bulunan artık değer olarak tanımlanmaktadır. Bu değişken kurumların karlılık seviyesini tam olarak göstermemekle birlikte, literatürde karlılık düzeyine belirlemede kullanılmaktadır. Ancak bu çalışmada kurumların kar marjını göstermek için Gilles et al. (2016) tarafından da tercih edilen gayrisafi işletme artığının kurumların katma değer toplamına oranı kullanılmıştır. $\mathrm{Bu}$ tercihin nedeni, söz konusu değişkene ait verilerin OECD ülkeleri açısından elde edilebilirliğinden dolayıdır.

1 Örneklemdeki ülkeler; Avusturya, Belçika, Çekya, Danimarka, Finlandiya, Fransa, Almanya, Yunanistan, Macaristan, İzlanda, İrlanda, İsrail, İtalya, Litvanya, Hollanda, Yeni Zelanda, Norveç, Polonya, Portekiz, Slovakya, Slovenya, İspanya, İsveç, İsviçre, İngiltere ve Amerika Birleşik Devletleri'nden oluşmaktadır. 


\subsection{Ekonometrik Yöntem ve Bulgular}

Çalışmada, panel regresyon analizi yapılmıştır. Regresyon analizinde öncelikle serilerin durağanlık seviyeleri incelenmiştir. Çünkü durağan olmayan seriler sahte regresyon problemine yol açmakta ve tahmin sonuçlarının tutarlılığını olumsuz yönde etkilemektedir. Durağanlık analizinin sonrasında ise hata terimlerine ilişkin temel varsayımların geçerliliği test edilerek model tahmin edilmiştir.

Panel regresyon analizi yapılmadan önce serilerin durağan olup olmadıklarına birim kök testleri aracılığıyla karar verilmelidir. Panel veri için Levin, Lin ve Chu (2002), Im, Pesaran ve Shin (2003) ve Maddala ve $\mathrm{Wu}$ (1999) tarafından geliştirilen birim kök testleri aracılığıyla ele alınan serilerin birim kök testleri yapılmıştır. LLC testinde "ortak birim kök vardır" şeklindeki sıfır hipotezi test edilirken; diğer testlerde "bütün i'lerde (yatay kesitlerde) birim kök vardır" şeklindeki sıfır hipotezi test edilmektedir. Test sonuçları aşağıdaki tabloda gösterilmiştir.

Tablo 2: Birim Kök Testi Sonuçları

\begin{tabular}{|l|c|c|c|}
\hline \multirow{2}{*}{ Variables } & $\begin{array}{c}\text { Levin, Lin \& Chu } \\
\text { (LLC) }\end{array}$ & $\begin{array}{c}\text { Im, Pesaran ve Shin } \\
\text { (IPS) }\end{array}$ & $\begin{array}{c}\text { Maddala ve Wu } \\
\text { (Fisher ADF) }\end{array}$ \\
\cline { 2 - 4 } & $\begin{array}{c}\text { Bireysel Sabitli ve } \\
\text { Trendli }\end{array}$ & $\begin{array}{c}\text { Bireysel Sabitli ve } \\
\text { Trendli }\end{array}$ & $\begin{array}{c}\text { Bireysel Sabitli ve } \\
\text { Trendli }\end{array}$ \\
\hline Corgdp & $-3.81(0,00)^{*}$ & $-3.87(0,00)^{*}$ & $94.81(0,00)^{*}$ \\
\hline Corrate & $-4.82(0,00)^{*}$ & $-0.15(0,43)$ & $51.84(0,32)$ \\
\hline Corratesq & $-8.61(0,00)^{*}$ & $-2.15(0,01)^{* *}$ & $79.71(0,00)^{*}$ \\
\hline Corshare & $-2.35(0,00)^{*}$ & $-1.84(0,03)^{* *}$ & $69.00(0,05)^{* * *}$ \\
\hline Profit & $-5.15(0,00)^{* *}$ & $-2.03(0,02)^{* *}$ & $72.73(0,03)^{* * *}$ \\
\hline Gdp & $-7.19(0,00)^{*}$ & $-3.41(0,00)^{*}$ & $92.49(0,00)^{*}$ \\
\hline Ratedif & $-6.12(0,00)^{*}$ & $-2.59(0,00)^{*}$ & $82.04(0,00)^{*}$ \\
\hline Unemp & $-4.14(0,00)^{*}$ & $-2.31(0,01)^{* *}$ & $77.07(0,01)^{* *}$ \\
\hline
\end{tabular}

Not: Gecikme uzunlukları Akaike kriteri ile otomatik olarak belirlenmiştir. Parantez içerisindeki değerler testlerin olasılık değerini göstermektedir. * \% 1 düzeyinde anlamlı olan test değerlerini; $* *$ ise $\% 5$ düzeyinde anlamlı olan test değerlerini göstermektedir.

Tablo 2'de görüldüğü gibi, bireysel sabitli ve trendli modelde serilerin birim kök içermediği, başka bir ifadeyle durağan oldukları sonucuna ulaşılmıştır. Serilerin durağan olduklarının test edilmesi sonrasında ise panel regresyon modeli tahmin edilmiştir. Ancak kurumlar vergisi oranları ile gelirler arasındaki ilişkiyi inceleyen modelin statik panel ile tahmin edilmesinden önce uygun panel tahmin modeli belirlenmiştir.

Statik panel verilerinin tahmininde sabit etkiler ve rassal etkiler modelleri kullanılabilmektedir. Sabit etkiler modeli, eğim katsayılarının zaman ve 
kesit birimleri için aynı olduğu ancak sabit katsayısının yatay kesit birimlere göre değiştiği modellerdir. Bu modelde yatay kesit birimleri arasındaki farklar sabit terimdeki farklılıklarla açıklanmakta ve model kukla değişken yardımıyla tahmin edilmektedir. Rassal etkiler modeli ise yatay kesit birimlerindeki farklılıkların hata terimi gibi rassal olduğu varsayılmaktadır. Rassal etkiler modelinde yatay kesit birimlerinde meydana gelen değişiklikler, modele hata teriminin bir bileşeni olarak dahil edilmektedir (Çalışkan 2009:125).

Analizde sabit ve rassal etkiler tahmincilerinden hangisinin tercih edileceğinin belirlenebilmesi için Hausman testi kullanılmıştır. Hausman testi, "rassal etkiler tahmincisi doğrudur" sıfır hipotezi altında k serbestlik dereceli ki-kare dağılımı göstermektedir. Değişkenlerin sabit etkiler ve rassal etkiler katsayılarını ve standart hatalarını içeren Tablo 3, Hausman testi sonuçlarını yansıtmaktadır.

Tablo 3: Hausman Testi Sonuçları

\begin{tabular}{|l|c|c|c|c|}
\hline & $(b)$ & $(B)$ & $(b-B)$ & Sqrt(Diag(V_b-V_B)) \\
\hline & Fixed & Random & Difference & S.E. \\
\hline Corrate & 1.88418 & 3.977651 & -2.09347 & 1.292229 \\
\hline Corratesq & 6.837139 & 2.906881 & 3.930258 & 2.181859 \\
\hline Corshare & 8.319342 & 5.343783 & 2.975558 & 1.808684 \\
\hline Profit & 1.958988 & 3.885059 & -1.92607 & 0.707056 \\
\hline Gdp & 0.024759 & 0.022358 & 0.002401 & 0.00064 \\
\hline Unemp & -0.08422 & -0.08425 & $2.55 E-05$ & 0.002211 \\
\hline Ratedif & 0.020455 & 0.017706 & 0.002749 & 0.002084 \\
\hline Chi2(7) & \multicolumn{5}{|c|}{0.1751} \\
\hline Prob>chi2 & \multicolumn{5}{|l}{} \\
\hline
\end{tabular}

Tablo 3'deki $\mathrm{P}$ değerinin 0,05 'ten büyük olması $\mathrm{H}_{0}$ '1n kabul edildiğini göstermektedir. $\mathrm{Bu}$ durum rassal etkiler modelinin varsayımlarının karşılandığ1 ve rassal etkiler tahmincisinin tutarlı olduğu anlamına gelmektedir. Hausmann Testi sonucunda rassal etkiler yönteminin sabit etkiler yöntemine kıyasla daha uygun olduğunu görülmüş ve model tahmin edilmiştir. Panel veri analizinde kullanılan rassal etkiler modelinde yatay kesit bağımlılığ 1 , değişen varyans ve otokorelasyon sorunlarının olmadığı varsayımı bulunmaktadır. Çünkü bu sorunlar, modeldeki katsayıların sapmalı tahmin edilmesine neden olmaktadır. Bu nedenle rassal etkiler modeli tahmin edildikten sonra bu varsayımların geçerliliği test edilmiştir. Analizde yatay kesit bağımlılı̆̆ olup olmadığını görmek amacıyla Pesaran (2004) tarafından önerilen test uygulanmış; değişen varyansın belirlenmesinde Lagrange Multiplier (LMh) testi kullanılmış; veri setinde otokorelasyonun olup olmadığ Wooldridge otokorelasyon testi ile araştırılmıştır. Her üç test sonucu da 
rassal etkiler model tahmin sonuçlarının sapmalı olduğunu; başka bir ifadeyle modelde yatay kesit bağımlılığı, değişen varyans ve otokorelasyon problemlerinin olduğunu göstermiştir.

Panel veri modellerinde değişen varyans, otokolerasyon ve yatay kesit bağımlılık durumlarının en az bir tanesi varsa, ya parametre tahminlerine dokunmadan standart hatalar düzeltilmeli (dirençli standart hatalar elde edilmeli) ya da varlıkları halinde uygun yöntemlerle tahmin yapılmalıdır (Tatoğlu 2012:241-242). Analizde Driscoll-Kraay tahmincisi ile varsayımdan sapmalar (değişen varyans, otokolerasyon ve yatay kesit bağımlılık) düzeltilmiştir. Tahmin sonuçları, Tablo 4'de gösterilmiştir.

Tablo 4: Rassal Etkiler Model Tahmin Sonuçları

\begin{tabular}{|l|c|c|c|c|}
\hline & Katsayılar & Standart Hatalar & $\mathbf{Z}$ & $\mathbf{P}>|\mathbf{z}|$ \\
\hline Corrate & 11.367 & 1.119 & 10.15 & $0.000^{*}$ \\
\hline Corratesq & -6.458 & 2.101 & -3.07 & $0.002^{*}$ \\
\hline Corshare & 4.485 & 0.191 & 23.38 & $0.000^{*}$ \\
\hline Profit & 11.823 & 0.183 & 64.53 & $0.000^{*}$ \\
\hline Gdp & -0.026 & 0.003 & -8.7 & $0.000^{*}$ \\
\hline Unemp & -0.115 & 0.001 & -59.89 & $0.000^{*}$ \\
\hline Ratedif & 0.006 & 0.001 & 3.5 & $0.000^{*}$ \\
\hline
\end{tabular}

Not: *, \% 1 seviyesindeki anlamlllık düzeyini göstermektedir.

Tablo 4'de görüldüğü üzere, kurumların katma değer toplamlarının GSYIH'ya oranı arttıkça kurumlar vergisi hasılatı artmaktadır. Bu sonuç beklentileri karşılamaktadır. Katma değer çok basit bir biçimde sadece girdi ve çıktı arasındaki farka indirgenmemeli; aksine teknoloji, inovasyon, AR-GE ve markalaşma gibi kavram ve olgulara dayandırılmalıdır. Katma değer bu boyutuyla ele alındığında, yüksek teknolojiye dayalı katma değeri yüksek ürün yelpazesiyle üretim yapan kurumların daha yüksek getiri ve dolayısıyla daha fazla vergi ödemeleri beklenen bir sonuçtur.

Analizde kullanılan bir diğer değiş̧ken kurumların işletme artığının katma değere oranıdır. $\mathrm{Bu}$ oran, kurum karlılığını göstermektedir. Bu nedenle karlılık ile ödenilen vergi arasında doğrusal bir ilişki beklenmektedir. Nitekim analiz sonuçları, karlılıktaki bir artışın kurumlar vergisi hasılatını arttırdığını göstermektedir.

Kişisel gelir vergisi oranından kurumlar vergisi oranının çıkarılması sonucu elde edilen değişken (ratedif), gelirin hangi vergi türüne kayacağını göstermektedir. Nitekim daha düşük kişisel gelir vergisi oranı kurumlar vergisi matrahından gelir vergisi matrahına doğru bir kaymaya neden olabilir. $\mathrm{Bu}$ değişkenin beklenildiği gibi pozitif çıkması, işletmelerin vergisel avantajlardan dolayı kurumsallaşma eğilimlerini 
arttırdığı ve buna bağlı olarak da daha fazla kurumlar vergisi ödediklerinin bir göstergesi olarak ele alınabilir.

Analizde kullanılan gelir (gdp) ve işsizlik (unemp) şeklindeki makroekonomik değişkenler ise istatistiksel açıdan anlamlı ve negatif işaretlidir. İşsizlik değişkeninin negatif işaretli olması, ekonomik istikrarsızlık dönemlerinde kurumlar vergisi hasılatında azalma olacağını göstermektedir ve bu yönüyle beklentilere uygundur. Ancak ekonomik büyümedeki bir artışın kurumlar vergisi hasılatını yükseltmesi beklenirken analiz sonuçları beklentilerin aksi yöndedir. Bu sonuç ancak kurumlar vergisinin gelir esnekliği ile açıklanabilir ve esneklik katsayısı düşük olduğundan hasılat artmamış denilebilir.

Kurumlar vergisi oranı ile kurumlar vergisi hasılatı arasındaki ilişki ise beklenildiği gibi pozitiftir. Vergi oranlarındaki bir artış kurumlar vergisi hasılatını arttırmaktadır. Bununla birlikte, kurumlar vergisi oranlarının karesi ile kurumlar vergisi hasılatı arasındaki ilişki de beklentilere uygun bir şekilde negatif işaretlidir. Bu sonuç, vergi oranları ile vergi hasılatı arasındaki doğrusal olmayan ilişkiyi göstermektedir. Bu çalışmanın temel amacı, oran ve hasılat arasındaki ilişkinin Laffer eğrisi formunda modellenmesi olduğundan, bu sonuçlara dayalı olarak OECD örneklemindeki ülkeler açısından Laffer eğrisi çizilmiştir.

Şekil 1: OECD Ülkelerine İlişkin Laffer Eğrisi (Kurumlar Vergisi Açısından)



Teorik olarak vergi gelirlerini ençoklaştıran vergi oranı, regresyon denkleminin corrate değişkenine göre türevi alınıp sıfıra eşitlenmesiyle 
bulunur $^{2}$. Ele aldığımız modelde vergi gelirlerini ençoklaştıran vergi oranı (optimum nokta) 0,34 olarak bulunmuştur. Şekil 1'de görüldüğü üzere, örneklemdeki OECD ülkelerinde ortalama kurumlar vergisi oranlarındaki bir artış karşısında kurumlar vergisi gelirlerinin GSYİH'ya oranı belli bir seviyeye kadar artmaktadır. Bu noktada vergi oranlarındaki bir artış karşısında vergi gelirlerinde ortaya çıkan artış gelir etkisi ile açıklanmaktadır. Vergi oranları belli bir seviyeye ulaştığında ise vergi gelirlerindeki artış durmakta ve vergi gelirleri maksimumum seviyeye ulaşmaktadır. Kurumlar vergisi gelirlerini maksimize eden bu oran \% 30'lar seviyesindedir. $\mathrm{Bu}$ oran aşıldıktan sonra ise vergi oranlarındaki artış vergi gelirlerini azaltmaktadır. Bu sonuç literatürde kurumlar vergisi paradoksu olarak adlandırılan ve kurumlar vergisi oranlar1 ile hasılat arasındaki ters yönlü ilişkinin örneklemdeki OECD ülkeleri açısından teyit edildiğini göstermektedir. Elde edilen bu sonuç, kurumlar vergisi oranlarında son dönemde yaşanan azalmaya karşın vergi hasılatındaki artışın amprik olarak test edilmesi açısından önemlidir. Nitekim analiz sonuçları, kurumlar vergisi politikası tasarımı açısından özellikle OECD ülkelerindeki gelişmelerin tutarlılığını göstermek yönüyle anlamlıdır.

\section{Sonuç}

Gelir üzerinden alınan vergilere dayalı bir vergi sistemi, kişisel gelir vergisi ve kurumlar vergisinden oluşmaktadır. $\mathrm{Bu}$ yönüyle hangi gelişmişlik seviyesinde olursa olsun her ülke, geliri elde eden kişinin kurumsal kimliğine dayalı olarak vergilemeye gitmektedir. Vergilemenin gelir üzerinden yapılması nedeniyle gelirin hangi vergi türüne tabi olacağı, küreselleşmenin ticari ilişkileri yoğun bir biçimde etkilediği son dönemde giderek önem kazanmıştır. Nitekim vergi rekabeti olgusunun ülkeler üzerindeki etkisi, kurumlar vergisi oranlarını azaltma eğilimlerini ortaya çıkarmaktadır. Bu eğilim, vergilemede kurumsallaşmanın önemini arttırarak gelir vergisi matrahlarından kurumlar vergisi matrahlarına doğru bir yönelişi tetikleyerek kurumlar vergisi hasılatının artmasına neden olmaktadır.

Günümüzde birçok ülkede kurumlar vergisi oranları azalma eğiliminde olmakla birlikte kurumlar vergisi gelirleri bu azalmadan fazla etkilenmemektedir. $\mathrm{Bu}$ durum kurumlar vergisi oranları ile hasılat arasında ters yönlü bir ilişki olup olmadığına yönelik çalışmaların artmasına neden olmuştur. Bu ilişkinin net bir biçimde ortaya konulması ülkelerin vergi sistemlerinin tasarımını etkilemektedir. $\mathrm{Bu}$ nedenle

\footnotetext{
${ }^{2} \mathrm{Bu}$ hesaplama Ek-1'de gösterilmiştir.
} 
kurumlar vergisi oran-hasılat ilişkisi önemli bir inceleme alanı olarak dikkat çekmektedir.

$\mathrm{Bu}$ çalışmada literatürde kurumlar vergisi paradoksu olarak ifade edilen ve küresel ölçekte birçok ülkede gözlemlenen kurumlar vergisi oranhasılat arasındaki ters yönlü ilişki ampirik olarak test edilmiştir. Analiz sonuçları, Laffer eğrisindeki teorik ilişkinin OECD ülkelerindeki kurumlar vergisi açısından geçerli olduğunu göstermiştir. Sonuçlar, kurumlar vergisi hasılatını maksimize eden oranın \% 34 seviyesinde olduğunu ve bu oranın üzerinde bir vergi oranının olması durumunda vergi oranlarındaki indirimlerin hasılatı arttırdı̆̆ını göstermiştir.

Çalışmanın sonuçları genel olarak değerlendirildiğinde, OECD ülkeleri açısından, kurumlar vergisi oran-hasılat ilişkisinin incelenmesi sonucunda iki temel çıkarım yapılabilir. Bunlardan birincisi, ülkeler artan rekabet koşullarında olduklarından gelir vergisi yerine kurumlar vergisine odaklanma eğilimdedir. Artan kurumsallaşma eğilimleri sonucunda ortaya çıkan bu durum, ülkelerin vergi politikası tasarımlarını etkilemektedir. İkinci ise ülkeler kurumlar vergisi oranlarını belirlerken ekonominin içsel dinamiklerini ve küresel koşulları dikkate almak durumunda olup; ideal bir vergi oranı belirleme noktasında hassas hareket etmelidir. Vergi politikasının tasarımı açısından oldukça önemli olan bu çıkarım; küresel ölçekte ortaya çıkan son dönemdeki gelişmelere amprik bir kanıt sunması açısından oldukça dikkat çekicidir.

\section{Kaynaklar}

Abbas, Ali ve Klemm, Alexander (2012). "A Partial Race to the Bottom: Corporate Tax Developments in Emerging and Developing Economies", IMF Working Paper, WP/12/28.

Albi, Emilio (2010). "The Challenges of Corporate Income Taxes in a Globalized World”, The Elgar Guide to Tax Systems, p.130-182.

Auerbach, Alan (2006). "Why Have Corporate Tax Revenues Declined? Another Look", NBER Working Paper Series, Working Paper 12463, (http://www.nber.org/papers/w12463, 10.04.2018'te erişildi).

Brender, Adi ve Politzer, Eran (2014). The Effect of Legislated Tax Changes on Tax Revenues in Israel. Research Department, Bank of Israel.

Brill, Alex ve Hassett, Kevin (2007). "Revenue-Maximizing Corporate Income Taxes: The Laffer Curve in OECD Countries". AEI Working Paper 137, July 31. 
Clausing, Kimberly (2007). "Corporate Tax Revenues in OECD Countries", International Tax and Public Finance, 14(2), 115-133.

Creedy, John ve Gemmell, Norman (2009). "Corporation Tax Revenue Growth in The UK: A Microsimulation Analysis", Economic Modelling, 26(3), 614-625.

Çalışkan, Zafer (2009). “OECD Ülkelerinde Sağlık Harcamaları: Panel Veri Analizi”, Erciyes Üniversitesi İktisadi ve İdari Bilimler Fakültesi Dergisi, (34), 117-137.

De Mooij, Ruud ve Nicodème, Gaetan (2007). "Corporate Tax Policy and Incorporation in the EU”, CEB Working Paper, N 07/016.

Devereux, Michael., Griffith, Rachel ve Klemm, Alexander (2002). "Corporate Income Tax Reforms and International Tax Competition”, Economic Policy, 17(35), 449-495.

Herbst, Karel (2008). Is The Concept of The Laffer Curve Valid? The Empirical Evidence from The Corporate Income Tax for Selected OECD Countries. Charles University in Prague Faculty of Social Sciences Institute of Economic Studies Master Thesis.

Im, Kyung So., Pesaran, Hashem ve Shin, Yongcheol (2003). "Testing for Unit Roots in Heterogeneous Panels" Journal of Econometrics, 115(1), 53-74.

Jahnsen, Kari ve Pomerleau, Kyle (2017). "Corporate Income Tax Rates around the World, 2017', Tax Foundation Fiscal Fact, No. 559.

Levin, Andrew., Lin, Chien-Fu ve Chu, Chia-Shang James (2002). "Unit Root Tests in Panel Data: Asymptotic and Finite-Sample Properties", Journal of Econometrics, 108(1), 1-24.

Maddala, Gangadharrao Soundalyarao ve Wu, Shaowen (1999). "A Comparative Study of Unit Root Tests with Panel Data and a New Simple Test", Oxford Bulletin of Economics and statistics, 61(S1), 631-652.

Mintz, Jack (1999). "Globalization of the Corporate Income Tax: The Role of Allocation", FinanzArchiv/Public Finance Analysis, 389423.

Monteiro, Marta Rodrigues., Brandão, Elisı Fernando ve Martins, Francisco Vitorino (2011). "A Panel Data Econometric Study of Corporate Tax Revenue in European Union: Structural, Cyclical Business and Institutional Determinants" FEP Working Papers, N. 437. 
Mooij, Ruud De ve Nicodème, Gaetan (2008). "How Corporate Tax Competition Reduces Personal Tax Revenue", CESifo DICE Report, 6(1), 27-31.

OECD (Ekonomik İşbirliği ve Kalkınma Teşkilatı) (2018). "Tax on Corporate Profits", (https://data.oecd.org/tax/tax-on-corporateprofits.htm, 02.05.2018'te erişildi).

Öncel, Yenal (2005). "Kurumlar Vergisinde Değişim ve Uluslararas1 Vergi Rekabeti”, Maliye Araştırma Merkezi Konferansları, (47), 120.

Pesaran, Hashem (2004). "General Diagnostic Tests for Cross Section Dependence in Panels", CESifo Working Paper Series, No. 1229.

Piotrowska, Joanna ve Vanborren, Werner (2008). The corporate income tax rate-revenue paradox: Evidence in the EU, Directorate General Taxation and Customs Union, European Commission.

Sørensen, Peter Birch (2007). "Can Capital Income Taxes Survive? And Should They?” CESifo Economic Studies, 53(2), 172-228.

Spence, Ian (1997). "Globalization of Transnational Business: The Challenge for International Tax Policy”, Intertax, 25, 143.

Stinespring, John (2009). "Are State Corporate Income Tax Rates Too High? A Panel Study of Statewide Laffer Curves", (https://pdfs.semanticscholar.org/f007/15afd3a87fa9b01555bea7ed ddacbe552683.pdf, 02.05.2018'te erişildi).

Swiston, Andrew., Mathai, Koshy ve Mühleisen, Martin (2007). "US Revenue Surprises: Are Happy Days Here to Stay?", IMF Working Paper, WP/07/143.

Şen, Hüseyin ve Sağbaş, İsa (2015). Vergi Teorisi ve Politikası. Ankara: Kalkan Offset.

Tatoğlu, Ferda Yerdelen(2012). Panel Veri Ekonometrisi: Stata Uygulamalı. İstanbul: Beta Basım Yayın.

Turhan, Salih (1998). Vergi Teorisi ve Vergi Politikast. Istanbul: Filiz Kitabevi.

Vogel, Lukas (2012). Tax Avoidance and Fiscal Limits: Laffer Curves in an Economy with Informal Sector. Directorate General Economic and Financial Affairs (DG ECFIN), European Commission.

Weichenrieder, Alfons (2005). “(Why) Do We Need Corporate Taxation?”, CESifo Working Paper 1495. 
EK-1: Vergi Gelirlerini Ençoklaştıran Hesaplama Yöntemi

$$
\begin{aligned}
& \frac{\text { dcorgdp }}{\text { dcorrate }}=0 \\
& \alpha+2 \text { corrate }=0 \\
& \text { corrate }=-\left(\frac{\alpha}{2 \beta}\right)
\end{aligned}
$$

$-\frac{13.62837}{(-19.62222) * 2}=\frac{13.62}{39.24}=0,34$ 
